\title{
PENDIDIKAN DAN NILAI NILAI MORALITAS DALAM AJARAN MAHABHARATA BAGI UMAT HINDU
}

\author{
Nurlensi \\ Institut Agama Hindu Negeri Tampung Penyang Palangkaraya \\ bawiayahfda@gmail.com
}

\begin{abstract}
Riwayat Jurnal
Artikel diterima : -

Artikel direvisi : :-

Artikel disetujui : :-
\end{abstract}

\begin{abstract}
Abstrak
Kitab Itihasa digambarkan sebagai "Itihasa mahapunyap" Itihasa mengandung nilai-nilai kebajikan yang utama (Adiparva, 112:16) dan sering juga disebut "punyap kathah" (cerita penuh kebajikan). Di dalam beberapa Itihasa yang umumnya mengutib kitab Mahbharata dapat ditemukan formulasi "atrapy udaharantimam Itihasa puratamam" sekarang mulai dengar cerita tentang Itihasa kuno. Cerita tentang Itihasa banyak mengandung unsur-unsur pendidikan dan hal ini sangat dominan di dalamnya. Jalinan sejarahnya seakan akan tidak nampak. Demikian dapat dijumpai dalam Mahabharata XII.391.14 "Sungguh tidak diragukan lagi, Itihasa disebut juga Viracerita atas Epos memuat berbagai aspek pemikiran keagamaan yang pada dasarnya tidak dapat dilepaskan dari bangsa Aria, baik berkaitan denga sejarah politiknya, sejarah keagamaan, maupun sejarah perkembangan ide-ide filsapat di India dan merupakan mata rantai yang tidak pernah putus dengan masa lampau, masa yang mendahuluinya, sering terjadi adanya masukan yang baru ke dalam yang lama, sehingga timbulah "Liberalisme konsevatf" dan hal ini yang mendorong tercapainya hasil hasil yang gemilang di lapangan kebudayaan dan peradaban India (Radharishnan, 1989:43).

Ramayana karya Maharsi Valmiki disebut Mahakavia yang artinya karya puisi yang besar (agung) yang memenuhi persyaratan sebuah naskah dalam bentuk puisi. Seperti telah umum diketahui bahwa Itihasa terdiri dari dua Epos besar (viracerita) yaitu Ramayana dan Mahabharata. Itihasa juga termasuk kitab Purana dinyatakan sebagai jantung hati, atau nurani dari ajaran Agama Hindu (Klostermaier, 1990:74), yang menunjukan kepada kita bahwa sumber ajaran Agama Hindu disamping tentunya Veda sebagai Wahyu Fuhan Yang Maha Esa adalah kitab Itihasa dan juga purana dalam kedua jenis kitab tersebut kita mendapatkan contoh pengamalan implementasi ajaran Agama Hindu untuk kehidupan sehari-hari. Lebih jauh kajian ini diharapkan bermanfaat bagi perkembangan kebudayaan nasional, khususnya pengembangan pendidikan nasional dalam rangka memperkokoh jati diri (identitas), citra bangsa dan memupuk serta meningkatkan patritisme dan nasionalisme untuk mencegah disetigrasi nasional yang gejalanya mulai nampak di Indonesia. Kata Kunci : Pendidikan, Nilai-nilai Moralitas, Mahabarata dan Umat Hindu
\end{abstract}




\section{Pendahuluan}

Ajaran Itihasa adalah bagian dari kesusastraan Hindu yang menceritakan kisah kepahlawanan para raja-raja dan kaum kesatria Hindu dimasa lalu dan dikombinasikan dengan filsapat Agama, mitologi dan cerita tentang makhluk supranatural, yang merupakan manifestasi kekuatan Brahman. Kitab Itihasa disusun oleh para Rsi dan pujangga dari India pada masa lalu. Seperti Rsi Walmiki dan Rsi Byasa. Itihasa yang terkenal ada dua yaitu Ramayana dan Mahabharata yang merupakan sastra klasik India yang besar sekali pengaruhnya terhadap sastra jawa kuno, disamping Ramayana dan Mahabharata disebut juga Astadasaparwa yang ceritanya dibagi ke dalam 18 parwa.

Kisah Mahabharata adalah cerita yang sangat terbesar perkembangannya dan terpanjang ceritanya yang merupakan salah satu dari dua epos Sansakerta utama dari India kuno. Bagian dari delapan belas parwa.

Buku ini disusun oleh Sri Byasa (Krishna Dwaipayana) yang merupakan kakek dari pahlawan, dia mengajarkan anaknya melakukan pengorbanan Yadnya. Nilai-nilai yang terkandung dalam Mahabharata diantaranya adalah nilai ajararan dharma, nilai kesaktian, nilai pendidikan dan nilai yadnya (korban suci) di dalam nilai dharma (kebenaran hakiki) dalam inti pokok cerita Mahabharata adalah konflik perang antara Pandawa melawan seratus Kurawa keturunan dari Bharata oleh karena itu Mahabharata disebut juga Maha Bharatayuddha. Konplik antara dharma (kebenaran atau kebajikan) yang diperankan oleh Panca Pandawa dengan adharma yang diperankan oleh seratus Kurawa. Dharma merupakan kebajikan yang tertinggi bagi kehidupan umat Hindu dalam cerita Mahabharata dalam tokoh pandawa lima dharma senantiasa menemaninya dalam setiap hal ditimbulkan oleh pikiran, perkataan dan perbuatan. Panca Pandawa dalam menegakkan dharma pada setiap langkahnya selalu mendapat ujian yang sangat berat, memuncak pada perang Bhratayuddha, bagi siapa saja yang berlindung pada dharma, Tuhan akan melindunginya dan memberikan kemenangan serta kebahagian, sebagaimana yang dilakukan oleh pandawa lima.

Nilai kesaktian (satya) dalam cerita Mahabharata mengandung lima 
nilai kesaktian (satya) yang dimiliki oleh Yudistira. Kelima nilai kesetian (satya) itu adalah : Satya wacana yang artinya satia atau jujur dalam berkata-kata, tidak berdusta, tidak mengucapkan kata-kata yang tidak baik, Satya hredaya yang artinya setia akan kata hati, berpendirian teguh dan tak terombang-ambing dalam menegakkan kebenaran. Satya laksana yang artinya setia dan jujur mengakui dan bertanggung jawab terhadap apa yang diperbuat. Satya mitra yang artinya setia kepada teman atau sahabat. Satya semaya yang artinya setia kepada janji.

Dalam sistem pendidikan yang diterapkan dalam cerita Mahabharata lebih menekankan pada penguasaan satu bidang keilmuan yang disesuaikan dengan minat dan bakat siswa artinya seorang guru dituntut memiliki kepekaan untnk mengetahui bakat dan kemampuan masing-masing siswanya. Sistem ini diterapkan oleh guru Drona. Bima yang memiliki tubuh kekar dan kuat dalam bidang keahlianya memainkan senjata gada, Arjuna mempunyai bakat dibidang senjata panah dididik menjadi ahli panah. Untuk menjadi seorang ahli mampu dibidangnya masing-masing, maka faktor displin dan kerja keras menjadi kata kunci dalam proses belajar mengajar.

Nilai yadnya (korban suci dan keiklasan) bermacam-macam yadnya dijelaskan dalam cerita Mahabhrata ada yadnya berbentuk benda, yadnya dengan tapa, yoga, yadnya mempelajari kitab suci, yadnya ilmu pengetahuan, yadnya untuk kebahagian orang tua, korban suci dan keiklasan yang dilakukan oleh seseorang dengan maksud tidak mementing diri sendiri dan menggalang kebahagian bersama adalah pelaksanaan dharma yang tertinggi (yajnam sanatanam). Kegiatan upacara Agama dan dharma sadhana lainnya sesungguhnya adalah usaha peningkatan kesucian diri, dalam kitab Manawa Dharmasastra, V.09 menyebutkan : tubuh dibersihkan dengan air, pikiran disucikan dengan kejujuran, atman disucikan dengan tapa brata, budhi disucikan dengan ilmu pengetahuan. Nilai-nilai dalam cerita Mahabhrata sangat relevan digunakan sebagai pedoman untuk menuntun hidup menuju ke jalan yang sesuai dengan Veda. Oleh karena itu kita mempelajari kitab suci Veda. Terlebih dahulu kita menguasai Itihasa dan Purana (Mahabharata dan Ramayana) seperti 
yang disebutkan dalam kitab Sarasamuscaya sloka 49 sebagai berikut : Veda itu hendaknya dipelajari dengan baik dan sungguh-sungguh dalam kehidupan kita dengan cara mempelajari Itihasa dan purana sebab Veda itu itu merasa takut akan orang-orang yang sedikit pengetahuannya.

\section{Pembahasan}

Dalam kitab Mahabharata menyajikan karya keseluruhan yang lebih besar dari karya yang homogen. Kitab ini mengandung suatu perbendaharaan yang sungguh-sungguh terhadap adat kebiasaan orang-orang India, baik itu sekuler maupun keagamaan. Tiada karya tersendiri yang memberikan pandangan ke dalam rahasia yang paling dalam tentang roh manusia, hal ini merupakan nyanyian kemenangan terhadap tingkah laku para pahlawan di dalam peperangan yang ditemukan terhadap balas dendam karena penghinaan perempuan dan utamanya mengadung kebenaran terhadap dinasti yang mengadakan perluasan wilayah kekuasaan kerajaan besar Bharata yang merajut bersama sama terhadap utara, timur, barat dan selatan india ke dalam suatu kerajaan ini merupakan Purana Samhita yang mengadung perluasan cerita tentang orang bijaksana dan orang yang melihat sebelumnya, kecantikan wanita dan kewajiban-kewajiban, tentang prajurit dan puisi raja-raja. Ini juga merupakan otoritatif dari buku-buku hukum moralitas, sosial, politik, filosofi yang membentang dalam pencapaian dharma artha dan karma yang disebut dengan tri varga dan juga menunjukan cara pembebasan serta menerangkan tentang filsafat agama yang tertinggi di India (Winternitz, 1990:410) lebih dari hal tersebut adalah tercapai tujuan hidup tertinggi umat manusia yakni moksa, bersatunya atma (jiwa individu) dengan brahman (Tuhan Yang Maha Esa).

Kitab Mahabharata digambarkan sebagai Ithihasa yang mengandung nilainilai kebajikan yang utama (Adiparwa, 112:16) dan sering juga disebut punyah kathah (cerita penuh kebajikan). Di dalam beberapa Itihasa yang umumnya mengutib kitab Mahabharata dapat ditemukan formulasi "atrapy udaharantinmam Itihasa purutamam" sekarang mulai dengar cerita Itihasa banyak mengandung unsur-unsur pendidikan, dan hal lain ini sangat dominan di dalamnya. Jalinan sejarah 
seakan akan tidak nampak. Demikian dapat dijumpai dalam Mahabharata XII. 391.14: "Sungguh tidak diragukan lagi, wahai Maha Rsi, seperti pisau belati yang dihujamkan ke hulu hati saya, air mata saya mengalir mendengarkan pembacaan kitab Itihasa, inilah puncak keriduan saya, semoga juga hal ini menentramkan hati kami”.

Maha Rsi Kautilya di dalam 2 slokanya (1.5 dan 10.15) memahami makna kitab Itihasa dalam pengertian kolektip yang terdiri dari 6 kelompok yaitu: Purana, Itivrtha, Akhyayika, Udaharana, Dharmasastra dan Arthsastra. Keseluruhan kelompok itu dianggap benar dan menyegarkan dalam memecahkan berbagai kesulitan. Kitab Mahabharata sendiri menyebutkan bahwa kitab ini adalah Itihasa yang terbaik (1.1.266) dan seterusnya. Lebih jauh dapat dipercaya bahwa dimasa yang silam India eksistensi Itihasa atau Itihasavada telah sangat merakyat dan populer, serta dinyatakan sebagai berikut: Di dalam pariplavan akhyanam, siklus Ritual selama 10 hari dari upacara asvamedha, dan diulangi dalam setahun, dalam upacara kuda yang dijadikan sasaran upacara itu mengembara seluas-luasnya setiap hari, diikuti oleh para petinggi dan sang Raja dan upacara ini dipimpin oleh seorang pandita yang disebut hort.

Hari pertama persembahan ditujukan kepada Manu Vaivasvata sebagai raja dan manusia sebagai rakyatnya dan matra-mantra dari kitab suci Rg Veda dirapalkan. Pada hari kedua persembahan ditujukan kepada Yama Vaivasvata, para pitara dan kanda ke-3 dari Yajur Veda yang dirapalkan, pada hari ke-3 ditujukan kepada Varuna Aditya, para Gandharva dan Parva dari Atharvanah. Pada hari ke-4 persembahan yang ditujukan kepada soma Vaisnava, para Apsara dan parva dari Angirasah yang dirapalkan. Pada hari ke-5 persembahan yang ditujukan kepada Arbuda Kadraveya dan para ular naga. Pada hari ke-6 persembahan yang ditujukan kepada Kubera Vasisravana, para raksasa dan parva Devajanavidya yang dirapalkan atau Roksaviya atau pascavidya. Pada hari ke-7 persembahan ditujukan kepada Asita Danvana para asura dan maya dengan pembacaan Asuravidya. Pada hari ke- 8 persembahan ditujukan kepada Matsya Sammada, monster air dan Itihasa dari Puranavidya yang dirapalkan. Pada hari ke-9 ditujukan 
kepada Tarksya Vaipasyasyata, raja burung dan purana dari purana Veda yang dirapalkan. Dan pada hari ke-10 ditujukan kepada dharma Indra, para dewata dan Sama Veda yang dirapalkan.

Menurut S.G. Kantawala (1989:89), Mahabharata merupakan kompedium berbagai lagenda, ceritacerita, pengajaran dan pendidikan, hukum, moral, filsafat dan sebagainya. Mahabharata juga disebut sebuah kavya (Adiparva:1.173) sebuah dharmasastra (Adiparva:56.21) dan sebuah cerita kepahlawanan (Itihasa) seperti dijumpai dalam Adiparva (56.21, 56.19, 1.17, 1.52, dan 56.18).

Berdasarkan kutipan di atas Mahabharata merupakan sebuah cerita berbingkai yang di dalamnya terkandung berbagai pengetahuan, moralitas, hukum, pendidikan budi pekerti, filsafat hidup, dan sebagainya. Mahabharata dikenal sebagai buku Itihasa, kata maha berarti besaratau agung, sedangkan kata bharata berarti raja- raja dari dinasti Bharata, jadi Mahabharata berarti cerita agung tentang keluarga Bharata. Raja-raja ini dikenal sebagai pandawa dan kaurawa. Buku Mahabharata menceritakan cerita kedua keluarga yang berakhir dengan kemusnahan keluarga kaurawa. Pada mulanya Maharsi Veda Vyasa, menulis kitab ini dengan nama "jaya samhita". Setelah itu Vaisampayana, muridnya sendiri dan setelah itu, Suta Ugasrava, juru cerita yang menceritakan cerita ini. Demikian Mahabharata terdiri dari tiga pangkalan perkembangan, yaitu berdasarkan penjelasan tersebut di atas, nama lain Mahabharata adalah "Satasahasri Samhita" yang mempunyai seratus ribu sloka (Mishra, 1988:18). Penjelasan tentang nama jaya dapat dijumpai dalam kitab Adi Parva (62.22). Parva pertama Mahabharata "jayo nametihaso yam Srotvyo vijigisuna" sedang nama Bharata Samhitam dijelaskan dalam Adiparva (1.78), “catur vimsaty sahasrim cekre bharata samhitam upakhyanairvina tavad bharatam procyate budhaih". Mahabharata disebut sebagai karya sastra, Ithasa atau Viracerita. Ramayana terdiri dari demikian banyak episode yang menunjukkan pula ditulis dalam beberapa periode oleh karena itu juga disebut sebagai "cycle of poems". Kisahnya adalah perang besar antara dua keluarga keturunan Bharata yaitu antara pandava dan kaurava dan karya ini oleh Akbar 
diterjemahkan ke dalam bahasa persia, namun karena kemunculan dewa-dewa ke bumi.

Kitab Mahabharata disusun dalam bentuk sloka yang jumlahnya puluhan ribu lebih, tidak ada suatu karya sastra di dunia ini yang tidak mengacu dan dijelaskan dalam kitab Mahabharata. Tidak ada satu karya sastra berupa viracerita (epik) didunia ini yang lebih besar dari Mahabharata. Menurut tradisi sastra india, kitab Mahabharata mengandung beberapa unsur yaitu ajaran tentang dharma, filsapat hidup, kesussastraan, musik, kesenian, bentuk bangunan, permainan, tari-tarian, ilmu nujum, ilmu falak (astronomi) dan sebagainya. Kitab Mahabharata dikenal juga sebagai Pancama Veda (Veda kelima). Tuhan Yang Maha Esa dalam wujudnya sebagai Krsna mengatakan rahasia atma (jiwa) kepada Arjuna dan jalan seseorang untuk membebaskan dirinya dari rangkaian hidup dan mati untuk mencapai moksa, bersatu kembali dengan Tuhan Yang Maha Esa.

Ramayana dan Mahabharata aslinya adalah cerita kepahlawanan, kemudian menjadi karya sejarah yang sangat erat berkaitan dengan sastra
Agama dan hal sangat penting sebagai dibuktikan oleh tanggapan masyarakat pada umumnya sebagai kebangkitan sekte, paksa atau sampradaya dalam Agama Hindu. Hal ini nampaknya sangat luas untuk secara tepat mencari bentuknya yang asli tentang kebenaran sejarah tersebut dan dalam Mahabharata bentuknya yang sekarang adalah suatu yang luar biasa dan yang seperti memberi petunjuk kepada kita tentang sisipan tidak berkesudahan tak terhitung merupakan suatu kebijaksanaan bagi pemiliknya.

Ramayana dan Mabharata adalah sesuatu yang mendalam lebih dari yang dirasakan setiap bagian dari karya sastra ini hendaknya dibaca sebagai titik tolak sejarah dimana hal tersebut dimunculkan. Para serjana rupanya sepakat bulat untuk membagi menjadi tiga esensial momen sejarah dari epik tersebut, dua hal nampaknya sama namun ketiga tahapan dapat dilihat dalam Mahabharata secara keseluruhan. Tetapi untuk yang pertama dan yang kedua dengan mudah dapat ditemukan dalam kitab Ramayana, sedangkan tahapan yang ketiga digambarkan agak samar di dalam kitab tersebut tetapi mendapatkan porsi yang 
besar dalam kitab Mahabharata. Ketiga tahapan tersebut adalah :

1. Itihasa disusun sebagai puisi populer, pada sekitar abad ke-6, ke-5 atau ke-4 sebelum masehi.

2. Itihasa berubah menjadi puisi yang bersifat sektarian oleh para pandita Vaisnava sekitar abat ke-2 sebelum masehi.

3. Ketuhanan yang berciri Vaisnava (Vaisnava theism) dalam kedua epik tersebut khususnya Mahabharata menjadi ensiklopedi agung tentang teologi, filsapat politik dan hukum, sekitar abad pertama atau ke-2 Masehi (Faquhar, 1984:44).

Tidak dapat dipungkiri oleh siapapun, bahwa kitab suci Veda adalah pustaka tertua umat manusia di muka bumi ini. Setelah kitab-kitab Veda (catur Veda Samhita) kemudian menyusul kitabkitab Brahmana, Aranyaka dan Upanisad, dan semua kitab-kitab tersebut dinyatakan sebagai bagian dan merupakan satu kesatuan dengan kitab catur Veda Samhita. Selanjudnya kitab-kitab Sutra, Smrti (Dharmasastra), Itihasa, Purana, dan kitab-kitab Darsana yang semuanya itu digolongkan ke dalam susastra Veda (Vedic Literature). Kitab-kitab Veda sangat populer dikalangan umat Hindu sebagai buku kecil yang merupakan himpunan wahyu Tuhan Yang Maha Esa. Merapalkan dan menyanyikan mantrammantram Veda, sampai kini masih dilakukan dalam rangka pemujaan dengan penuh kebahagian. Ide yang segar dan indah dalam kitab suci $\mathrm{Rg}$ Veda, umat mengikuti pedoman upacara yajna dalam Yayur Veda, merapalkan mantrammantram pemujaan yang diiringi irama musik yang diambil dari Sama Veda, demikian beberapa tradisi yang baik yang termuat dalam Atharva Veda menunjukkan bukti bahwa kitab suci Veda masih dilestarikan sepanjang masa. Selanjudnya Itihasa pada sisi yang lain, mengembangkan spirit dan ajaran yang terkandung dalam kitab suci Veda, utamanya keagungan para maharsi dan pahlawan yang terdapat dalam kitab suci Veda dengan menceritakan kembali ajaran atau cerita yang populer di dalam Veda. Itihasa merupakan sumber pertama cerita-cerita kepahlawanan dan beberapa tokoh dihubungkan dengan para maharsi dalam kitab suci Veda seperti Bhrgu, Atri, Vasistha, Jamadagni, Bharadvaja dan Visvammitra serta pahlawan besar dalam Veda seperti Manu, Nahusa, 
Yayati, Purarava, Yadhu, Prthu dan yang lain-lain.

Itihasa mencatat gambaran yang sangat luas tentang sejarah peradaban masa yang silam. Kebangkitan dan supremasi bangsa Arya terhadap anak Benua India, oleh karenanya sangat dekat hubungannya dengan kitab suci Veda dan studi terhadap Itihasa sejak berabat-abad silam merupakan salah satu bagian dari studi Agama Hindu di India. Itihasa mempopulerkan upacara-upacara dalam Veda, pahala yang diperoleh oleh orang yogi, filsafat kelepasan (ketidak terikatan) dan berbagai kebijakan serta kebajikan yang dijelaskan dalam Veda melalui cerita tentang keagungan para maha rsi dan raja rsi.

Itihasa membangkitkan kesadaran untuk manusia tentang ajaran moralitas kebijaksanaan dan tradisi yang baik dimasa yang silam diabadikan di dalam kitab-kitab Itihasa, kitab-kitab Viracerita ini menyampaikan misi suci tentang spirit dan makna upacara-upacara Veda, kedermawanan (dana punya), pantangan (tapa dan brata ), upacara penyucian diri (prayascitta dan tirtayatra) hari-hari raya mantra-mantra pemujaan, disiplin dan ajaran moralitas. Interprestasi tentang tujuan dan kehidupan yang ideal umat manusia terkandung dalam ajaran dharma yang merupakan hukum yang kekal abadi yang diwedarkan dalam Itihasa menjadikan umat manusia sangat menyadari makna filsapat dan ajaran moralitas agama yang hingga saat ini masih diikuti dan mejadi sumber inspirasi bagi umat manusia diberbagai belahan dunia. Penghargaan yang tertinggi terhadap nilai-nilai kehidupan dari keagungan sejarah atau Itihasa merupakan warisan yang sangat berharga. Bagi umat Hindu Itihasa maupun Purana sangat penting peranannya dalam menjelaskan dan menyebarkan ajaran yang terkandung dalam kitab suci Veda, sebagai dinyatakan dalam kitab Adiparva Mahabharata berikut :

YathaitantanItihasanam tatha bharatam ucyate, Yascainam sravayecchsraddhe brahmananpadamantatah Aksayyamantrapanam vaipitrmstasyopatishate, Itihasa puranabhyamVedarh samupbrhayet Bibheyyalpasrutatad vedo mamayam prharisyati KarsnamVedamimam Vidvacachsravayitvarthmasnute (M.B. Adivarva : 1.264-266) Artinya : Demikian kedudukan kitab 
Mahabharata di antara kitab-kitab sejarah. Tidak kekurangan apapun makanan dan minuman dan tidak pernah habis-habisnya (dipersembahkan oleh anak cucu) demikianlah kitab Veda hendak nya dijelaskan melalui kitab-kitab Itihasa dan Purana.

Mahabharata adalah sejarah diantara semua sejarah, ia yang menjadikan seorang Brahmana berkenan membaca walaupun hanya satu baris pada saat Upacara Sradha, persembahan kepada roh suci leluhur yang telah meninggal dunia, berupa makanan dan minuman, hal itu (pahalanya). Veda merasa takut kalau seorang bodoh membacanya. Veda berpikir bahwa dia (orang yang bodoh) akan memukulku. Orang yang terpelajar yang berkenan membaca kitab suci Veda dan Mahabharata akan memperoleh keberuntungan.

Dilihat dari isinya, sesuai dengan sloka dalam Adiparva, maka kitab Mahabharata digambarkan sebagai kitab Dhasastra, sebagai Arthsastra, sebagai kamasastra dan sebagai Moksasastra. A.N Juni (1980:69) menambahkan, bahwa Mahabharata merupakan kompedium berbagai legenda, cerita-cerita pengajaran dan pendidikan, hukum, moral, filsapat, dan sebagainya.

\section{Penutup}

Dari uraian di atas bahwa pendidikan dan nilai-nilai dalam ajaran Mahbharata sesungguhnya merupakan tuntunan mulia untuk seluruh umat manusia diseluruh dunia, sejak masa yang silam hingga dewasa ini masih relavan, certa ini antara seperti amrta, sama seperti sungai gangga yang maha suci (natama). Mahabharata merupakan sebuah cerita berbingkai yang di dalamnya terkandung berbagai pengetahuan, moralitas, hukum, pendidikan budi pekerti, filsapat hidup, cerita kepahlawanan dan sebagainya.

Menurut tradisi sastra india, kitab Mahabharata mengandung beberapa unsur yaitu : ajaran tentang dharma, filsapat Hindu, kesusastraan, musik, kesenian, bentuk bangunan, permainan, tari-tarian, ilmu nujum, ilmufalak, (astronomi) dan sebagainya. Kitab Mahabharata dikenal sebagai Pancama Veda (Veda kelima) Tuhan Yang Maha Esa dalam wujud-Nya sebagai Krsna mengatakan rahasia atma (jiwa) kepada Arjuna dan jalan seseorang untuk membebaskan dirinya dan rangkaian hidup dan mati untuk mencapain moksa. 


\section{Daftar Pustaka}

Atlekar, G . S. 1987. Studies on Valmiki Ramayana. Poona, India : Bhandarkar Oriental Research Institute.

Farquhar, J. N. 1984. An Outline of the Religious Literature of India. Delhi, India : Motilal Bana rsidass.

Kantawala, S. G. 1989. Marriage and Family in The Mahabharata: Sme Aspects dalam Moral Dilemmas in the Mahabharata. New Delhi : Motilal Bana rsidass.

Krishna Kumar. 1989. Vaidika Sahitya Ka Itihasa (History of Vedic Literature). Sahitya Bhandar : Meerutjndia.

Kushwaha, Rajendra Singh. 2003. Glimpses of Bjaratoua History. New Delhi, India : Ocean Books Pvt. Ltd.

Lai, P. 1991. The Ramayana of Valmiki. Terjemahan Djoko-lelono. Jakarta : Pusaka Jaya.

Mani, Vettam. 1989. Puranic Encylopaedia. New Delhi, India : Motilal Bana Rsidass.

Mardi Warsito, L. 1981. Kamus Bahasa Jawa Kuno. Endeh, Flores : Nusa Indah.

Masih, Yakub. 1983. The Hindu Religious Thought. New Delhi, India: Motilal Bana Rsidass. 